\title{
How are Interactions Taken into Account in Studies on Conventional and Complementary Therapies for Breast Cancer Patients with Menopausal Complaints?
}

\author{
Wie werden Interaktionen in Studien zur konventionellen und komplementären Therapie \\ bei menopausalen Beschwerden von Brustkrebspatientinnen berücksichtigt?
}

Authors

Affiliations

\section{J. Hübner ${ }^{1}$, K. Münstedt ${ }^{2}$, R. Mücke ${ }^{3}$, O. Micke ${ }^{4}$}

${ }^{1}$ Dr. Senckenbergisches Chronomedizinisches Institut, Universität Frankfurt, Frankfurt

${ }^{2}$ Frauenklinik, Universitätsklinikum Gießen, Gießen

${ }^{3}$ Strahlentherapie, Klinikum Lippe, Lippe

${ }^{4}$ Strahlentherapie, Franziskus Hospital, Bielefeld

\section{Key words}

- breast cancer

- antihormone therapy

- hormone withdrawal signs

- complementary medicine

- interactions

Schlüsselwörter

- Mammakarzinom

- antihormonelle Therapie

- Hormonentzugserscheinungen

- Komplementärmedizin

- Interaktionen

\section{received $\quad 15.6 .2012$ \\ revised $\quad 4.9 .2012$ \\ accepted $\quad 4.9 .2012$}

Bibliography

DOI http://dx.doi.org/

10.1055/s-0032-1327854

Geburtsh Frauenheilk 2012; 72 :

933-939 @ Georg Thieme

Verlag KG Stuttgart · New York . ISSN 0016-5751

\section{Correspondence}

\section{Dr. Jutta Hübner}

Universität Frankfurt

Dr. Senckenbergisches

Chronomedizinisches Institut

Theodor-Stern-Kai 7

60590 Frankfurt

huebner@med.uni-frankfurt.de

\section{Abstract}

\section{$\nabla$}

Introduction: Postmenopausal symptoms in breast cancer patients undergoing antihormone treatment lead to high drop-out rates from the therapy. From the therapeutic point of view, methods of both conventional and complementary medicine are concerned. Interactions are being discussed in cases of natural substances. However, they are also relevant for conventional medical substances. The aim of this analysis is to answer the question as to what extent potential interactions are taken into account in clinical studies and reviews on supportive therapies.

Materials and Methods: Clinical studies and reviews were identified by means of a systematic search and analysed with regard to the consideration of potential interactions.

Results: Altogether 46 clinical studies and one Cochrane review were found. Among the 35 studies on conventional drug therapies, 5 (14\%) took possible interactions into account. Among the 17 studies on complementary medicine, there were 2 (11.7\%) such publications. The Cochrane review did not mention interactions.

Discussion: For future studies in which interactions cannot be excluded, a strategy to control for their clinically relevant consequences should be developed. The present authors suggest that the use of survival and recurrence data as secondary endpoints, also for studies on purely supportive therapies, is a reasonable approach. The resulting considerations for study routines are listed thematically.

\section{Introduction}

\section{$\nabla$}

Menopausal complaints are a frequent phenomenon in patients with breast cancer. They are triggered or, respectively, intensified not only in the course of primary or adjuvant chemo- or antihor-

\section{Zusammenfassung \\ $\nabla$}

Einleitung: Postmenopausale Symptome bei Mammakarzinompatientinnen unter antihormoneller Therapie führen zu einer hohen Abbrecherrate der Therapie. Therapeutisch kommen Methoden der konventionellen wie der komplementären Medizin infrage. Bei den natürlichen Substanzen werden Interaktionen diskutiert. Sie betreffen aber auch Substanzen der konventionellen Medizin. Ziel der Analyse ist die Frage, inwieweit in klinischen Studien und Reviews zur supportiven Therapie potentielle Interaktionen berücksichtigt werden.

Material und Methodik: Mittels systematischer Recherche wurden klinische Studien und Reviews identifiziert und im Hinblick auf die Berücksichtigung möglicher Interaktionen analysiert.

Ergebnisse: Es wurden 46 klinische Studien und ein Cochrane-Review erfasst. Von den 35 Studien zur konventionellen medikamentösen Therapie berücksichtigten 5 (14\%) evtl. Interaktionen. Von 17 Studien zur Komplementärmedizin waren es 2 Arbeiten (11,7\%). Das Cochrane-Review geht nicht auf Interaktionen ein.

Diskussion: Für zukünftige Studien sollte bei nicht auszuschließender Interaktion eine Strategie zur Kontrolle der klinisch relevanten Folgen erarbeitet werden. Die Autoren schlagen hierfür Überlebens- und Rezidivdaten als sekundäre Endpunkte auch bei rein supportiven Therapiestudien als sinnvollen Ansatz vor. Die sich hieraus ergebenden Überlegungen für den Studienalltag werden im Artikel thematisiert.

mone therapy for younger women bur also by antihormone therapy for postmenopausal women. According to literature data about $40-50 \%$ of all breast cancer patients suffer from postmenopausal symptoms. 
The most disturbing symptoms thereby are hot flushes, mood fluctuations and fatigue. This leads in a not negligible number of patients to poor compliance or even to termination of the therapy. For antihormone therapy statistics show that up to $50 \%$ of the patients do not hold to the recommended therapy duration of 5 years, whereby the grey zone is assumed to be very large [1-4].

Unfortunately it is also possible that this has a negative effect on the prognosis for the patients.

Accordingly, informing the patients about the possibilities of the respective supportive therapies and their practical application is of particular significance for the therapeutic success. In such situations, the patients may also express the wish for a "natural" therapy. In the past years the attention of oncologists has been directed towards the interaction potential of, above all, phytotherapeutic agents [5]. Well known and commonly used substances are St. John's wort or grapefruit juice. Interactions between drugs or also with nutritional supplements may be based on their different mechanisms of action. Best known are the influences on pharmacokinetics exerted by the action of cytochrome P 450 enzymes (especially CYP 450 3A4, but also Pgp and in gynaecological oncology 2D6). These interactions have an impact not only on the first-pass metabolism but also on the formation of active metabolites. The effects can vary widely from patient to patient and depend, among others, on the individual enzyme constellations as well as on other confounding factors such as additional co-medications, nutrition, etc. Further interactions are possible via the direct action on the same target structures in the cell (receptors, molecules in the signalling chains), as well as in the surroundings of the receptors. The bioavailability of drugs can result from influences on transport molecules as well as direct chemical interactions. The latter mechanism is well known for $\mathrm{pH}$ shifts in the gastrointestinal tract or for the direct chemical interaction of two molecules such as, e.g., bortezomib and catechins from green tea [6,7].

However, potential interactions are, of course, not limited to complementary medicine, but also are involved in the substances of conventional medicine.

Every 4th tumour patient is endangered by interactions between chemotherapy, supportive therapy and/or drugs for co-morbidities [8].

Accordingly in studies on new drugs, increasingly comprehensive lists of drugs and natural substances that should not be consumed during the study period are being compiled. Known preclinical and clinical, especially pharmacological, data on interactions provide the basis for the exclusion of drugs.

For patients undergoing adjuvant antihormone therapy the question of interactions is of particular importance as this is a curative situation and, simultaneously, a possible negative influence may only be detected later when, probably, a connection with drug causing the interaction can no longer be demonstrated. At the same time the occurrence of metastases means an incurable and ultimately fatal situation for a great majority of the patients.

Thus, the target of a supportive therapy in breast cancer is to avoid the hormone withdrawal symptoms induced directly by the antihormone therapy without reducing the antihormone action on the tumour cells. Especially in cases of receptor-positive tumours, care must be taken that the supportive therapy does not lead to an improvement of the menopausal symptoms by directly or indirectly triggering a hormone or hormone-like activity.
The aim of the authors is to analyse to what extent in the past years clinical studies on supportive therapy for menopausal symptoms that have been induced by an adjuvant therapy for breast cancer have taken the topic of potential interactions into account.

\section{Material and Methods}

$\nabla$

From a Medline search (search day: 2012-03-31), we extracted all articles on clinical studies or reviews and meta-analyses on symptom control for menopausal complaints in patients with breast cancer.

Our search strategy is presented in Box 1. The search was limited to articles that were available as full texts. Besides Medline, the Cochrane library was used regarding reviews on supportive therapies for breast cancer. Articles on purely psycho-oncological procedures including behavioural therapy and physical activity as well as methods such as Tai Chi, Qigong and Yoga were excluded from the start, since therapeutic interactions probably do not play an essential role in these processes.

Search strategy and terms used to identify publications

MeSH terms search:

1. breast cancer

Direct keyword search:

1. hot flushes

2. vasomotor symptoms

3. menopausal symptoms

4. osteoporosis

5. tamoxifen

6. letrozol

7. anastrozol

8. exemestan

9. fulvestrant

10. ([2]or[3]or[4]or[5])

11. ([6]or[7]or[8]or[9]or[10])

12. ([11] AND [1])

13. ([11] AND [12])

14. ([13]or[14])

Limits: clinical study, review, meta-analysis;

language: English

On the basis of the title and abstract, we checked whether the article presented a controlled clinical study on supportive therapy for menopausal symptoms or, respectively, a corresponding review or meta-analysis. Subsequently the article was analysed as to whether the topic of interactions was recognisably taken into consideration. Two criteria were applied for this:

1. Does the article contain an argumentation taking the topic into consideration? And has a possible interaction already been excluded with certainty during the study planning on the basis of unambiguous published data?

2. When an interaction cannot be excluded with certainty: was the measurement of parameters that were suitable to answer questions about interactions (survival data: disease-free survival and overall survival) planned and documented?

3. When 1 or 2 was not fulfilled: were considerations on possible interactions included in the discussion? 


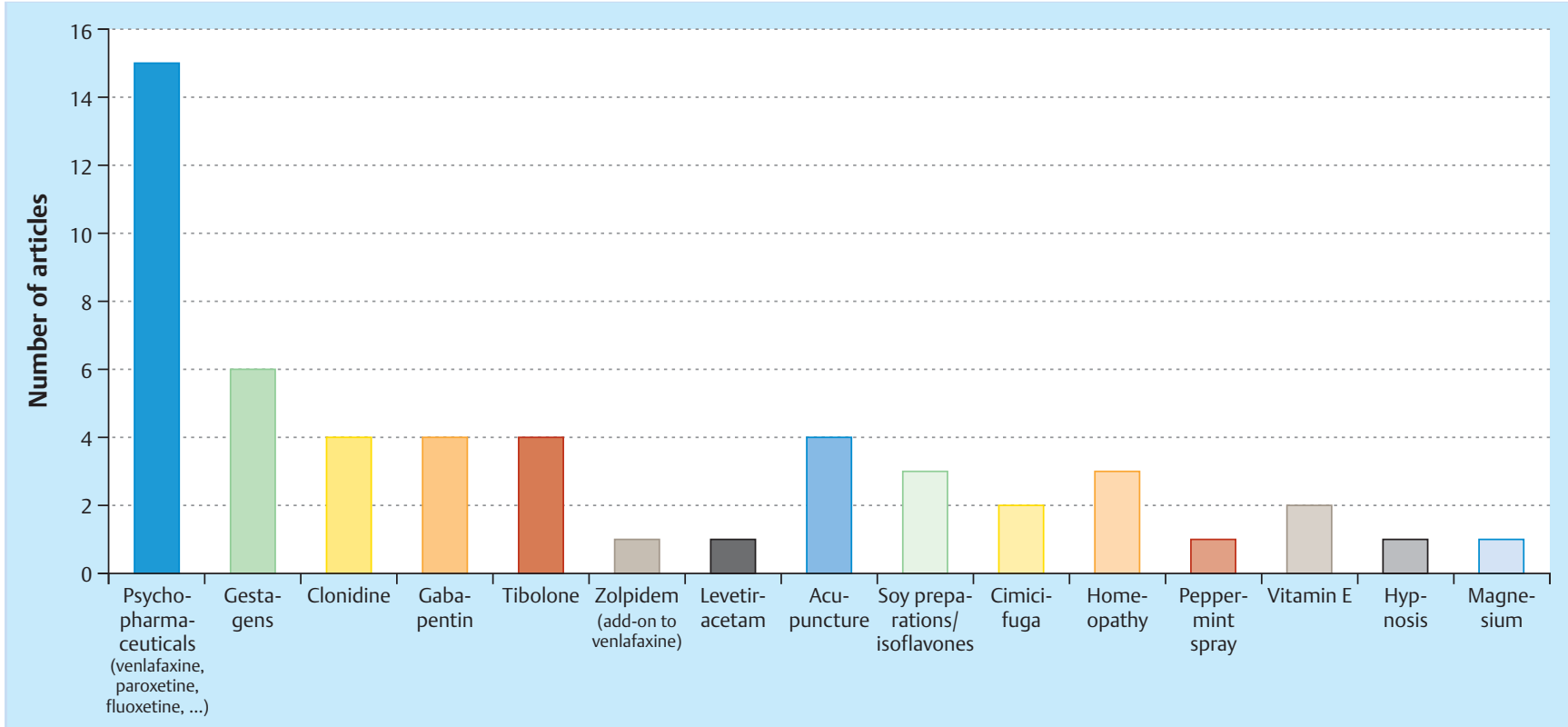

Fig. 1 Due to the fact that in some studies different substances were being compared in two active study arms, the total of studies exceeds 46.

4. In addition, we checked whether the documented side effects were suggestive of possible interactions.

\section{Results}

\section{$\nabla$}

Altogether between 1994 and 2010, 45 clinical studies (references [9-56]) on menopausal complaints in patients with breast cancer and one Cochrane review were published. Except for 4 , all were published in journals that can be assigned to the field of conventional medicine. Articles on complementary therapeutic procedures such as phytopharmaceuticals, vitamin E and acupuncture also appeared in part in oncological journals with high impact factors (Journal of Clinical Oncology, Annals of Oncology). A survey on the topics and number of articles in which a specific substance was tested is given in $\bullet$ Table $\mathbf{1}$ and Fig. $\mathbf{1 .}$

Altogether conventional drug therapies were tested 35 times in controlled studies. In 5 articles (14\%) the possibility of an interaction and thus a negative effect on the antihormone therapy was discussed ( 2 studies on tibolone, 1 each on gabapentin, paroxetine and megestrol acetate). These articles dated from the years 1994, 2000, 2 from 2005, and 2009.

Methods of complementary therapy were tested 17 times. Of these 2 articles (11.7\%) from the years 2001 and 2003 discussed the possibility of interactions (both studies on Cimicifuga).

Of these 35 studies, only 4 ( $9 \%$ of all publications) have collected data that allow the assumption of clinically relevant interactions. These are two studies on tibolone (survival; activity on the endometrium) and the 2 studies on Cimicifuga (recurrence control every 2 months; measurements of FSH and LH).

Besides possible interactions, the question of side effects is also important with regard to therapeutic safety. Of the 35 studies on conventional therapy, side effects were reported in 32 studies. Of the 16 studies on complementary therapy, 8 mentioned side effects. Among the articles on conventional therapy, type, extent and frequency of the side effects were given in comparison to a control group whereas the studies on complementary therapy were usually limited to comments on the generally good tolerability.

The Cochrane review by Rada et al. [47] collected all non-hormonal interventions together. Data on vitamin E, clonidine, ergotamine, phenobarbital, Belladonna, gabapentin, SSRIs and SNRIs (venlafaxine, paroxetine, sertraline, fluoxetine, mirtazapin, trazodone) as well as non-drug therapies such as meditation, Ayurveda, aroma therapy, acupuncture, magnetic therapy, relaxation procedures, biofeedback, hypnosis, behavioural therapies including respiration therapy and sports. Explicitly excluded were herbal oestrogens (isoflavones from soy and red clover), Cimicifuga and tibolone on the basis of their oestrogen-like mechanisms. The Cochrane review does not deal with interactions between antihormone therapy and the various pharmacological procedures. Also the question of a possible impact on disease course, progress and survival was not discussed.

\section{Discussion}

Altogether, the topic of interactions was taken into consideration in merely 7 of the 45 articles, and there was no difference in frequency between articles on conventional and complementary medicine.

It could be expected that the consideration of interactions would have increased after the interactions of St. John's wort became known. However this is not the case, either in conventional supportive therapy or in complementary medicine [8].

It cannot be assumed from this lack of consideration in the articles that the topic was indeed ignored by the authors, rather they may have made such considerations while planning the study and then dismissed the possibility of interactions for the chosen test substances.

The latter argumentation is, however, unlikely since conventional substances that are metabolised via CYP 450 3A4 or CYP 450 2D6 
Table 1 Survey of studies on supportive therapy for menopausal complaints under endocrine therapy for patients with breast cancer.

\begin{tabular}{|c|c|c|c|c|}
\hline Author & $\begin{array}{l}\text { Publica- } \\
\text { tion year }\end{array}$ & Study name & Location & Summary of contents \\
\hline Barton & 1998 & $\begin{array}{l}\text { Prospective evaluation of vitamin } \mathrm{E} \text { for hot flashes in breast } \\
\text { cancer survivors. }\end{array}$ & Rochester & $\begin{array}{l}\text { Vitamin E vs. placebo; significant difference } \\
\text { without clinical relevance; patients did not prefer } \\
\text { verum }\end{array}$ \\
\hline Barton & 2002 & Depomedroxyprogesterone acetate for hot flashes. & Rochester & $\begin{array}{l}\text { Medroxyprogesterone i.m. pre-post comparison } \\
\text { effective }\end{array}$ \\
\hline Bertelli & 2002 & $\begin{array}{l}\text { Intramuscular depot medroxyprogesterone versus oral } \\
\text { megestrol for the control of postmenopausal hot flashes in } \\
\text { breast cancer patients: a randomized study. }\end{array}$ & $\begin{array}{l}\text { Cuneo, } \\
\text { Italy }\end{array}$ & $\begin{array}{l}\text { Medroxyprogesterone i. m. vs. megestrol p. o.; } \\
\text { no difference under the therapy, longer effect } \\
\text { of i. m. therapy }\end{array}$ \\
\hline Biglia & 2005 & $\begin{array}{l}\text { Evaluation of low-dose venlafaxine hydrochloride for the therapy } \\
\text { of hot flushes in breast cancer survivors. }\end{array}$ & Turin & $\begin{array}{l}\text { Venlafaxine; open study; significant improvement } \\
\text { in pre-post comparison }\end{array}$ \\
\hline Biglia & 2009 & $\begin{array}{l}\text { Non-hormonal treatment of hot flushes in breast cancer } \\
\text { survivors: gabapentin vs. vitamin E. }\end{array}$ & Turin & $\begin{array}{l}\text { Vitamin Evs. gabapentin; improvement with } \\
\text { gabapentin; vitamin E without effect }\end{array}$ \\
\hline $\begin{array}{l}\text { Borde- } \\
\text { leau }\end{array}$ & 2010 & $\begin{array}{l}\text { Multicenter, randomized, cross-over clinical trial of venlafaxine } \\
\text { versus gabapentin for the management of hot flashes in breast } \\
\text { cancer survivors. }\end{array}$ & Ontario & $\begin{array}{l}\text { Comparison of venlafaxine and gabapentin; } \\
\text { patients preferred venlafaxine }\end{array}$ \\
\hline Buijs & 2009 & $\begin{array}{l}\text { Venlafaxine versus clonidine for the treatment of hot flashes in } \\
\text { breast cancer patients: a double-blind, randomized cross-over } \\
\text { study. }\end{array}$ & Groningen & $\begin{array}{l}\text { Venlafaxine vs. clonidine; both moderately active; } \\
\text { venlafaxine had more side effects }\end{array}$ \\
\hline $\begin{array}{l}\text { Car- } \\
\text { penter }\end{array}$ & 2007 & $\begin{array}{l}\text { Evaluating the role of serotonin in hot flashes after breast cancer } \\
\text { using acute tryptophan depletion. }\end{array}$ & $\begin{array}{l}\text { Indiana- } \\
\text { polis }\end{array}$ & $\begin{array}{l}\text { Effect of tryptophan depletion on menopausal } \\
\text { symptoms: no deterioration }\end{array}$ \\
\hline Clover & 2002 & Homeopathic treatment of hot flushes: a pilot study. & $\begin{array}{l}\text { Tunbridge } \\
\text { Wells }\end{array}$ & Homeopathy effective in case series \\
\hline Deng & 2007 & $\begin{array}{l}\text { Randomized, controlled trial of acupuncture for the treatment } \\
\text { of hot flashes in breast cancer patients. }\end{array}$ & New York & $\begin{array}{l}\text { Acupuncture vs. sham-acupuncture; no significant } \\
\text { difference }\end{array}$ \\
\hline Dyer & 2008 & $\begin{array}{l}\text { A study to look at the effects of a hydrolat spray on hot flushes } \\
\text { in women being treated for breast cancer. }\end{array}$ & London & $\begin{array}{l}\text { Spray with peppermint and neroli vs. spray with } \\
\text { water; peppermint spray marginally better }\end{array}$ \\
\hline Elkins & 2008 & $\begin{array}{l}\text { Randomized trial of a hypnosis intervention for treatment of hot } \\
\text { flashes among breast cancer survivors. }\end{array}$ & Waco, USA & $\begin{array}{l}\text { Hypnosis vs. no therapy; hypnosis lead to a signifi- } \\
\text { cant improvement of symptoms }\end{array}$ \\
\hline Frisk & 2008 & $\begin{array}{l}\text { Long-term follow-up of acupuncture and hormone therapy } \\
\text { on hot flushes in women with breast cancer: a prospective, } \\
\text { randomized, controlled multicenter trial. }\end{array}$ & $\begin{array}{l}\text { Linköping, } \\
\text { Sweden }\end{array}$ & $\begin{array}{l}\text { Electro-acupuncture vs. hormone therapy; } \\
\text { hormone therapy is more effective but electro- } \\
\text { acupuncture is also effective }\end{array}$ \\
\hline $\begin{array}{l}\text { Gold- } \\
\text { berg }\end{array}$ & 1994 & $\begin{array}{l}\text { Transdermal clonidine for ameliorating tamoxifen-induced } \\
\text { hot flashes. }\end{array}$ & $\begin{array}{l}\text { Danville, } \\
\text { USA }\end{array}$ & $\begin{array}{l}\text { Clonidine vs. placebo; significant effect, clinical } \\
\text { limited but with marked side effects }\end{array}$ \\
\hline Goodwin & 2008 & $\begin{array}{l}\text { Phase III randomized placebo-controlled trial of two doses } \\
\text { of megestrol acetate as treatment for menopausal symptoms } \\
\text { in women with breast cancer: Southwest Oncology Group } \\
\text { Study } 9626 \text {. }\end{array}$ & $\begin{array}{l}\text { Spring- } \\
\text { field, USA }\end{array}$ & $\begin{array}{l}\text { Comparison of } 21 \text { doses of megestrol acetate; } \\
\text { both effective, } 20 \mathrm{mg} \text { recommended for therapy }\end{array}$ \\
\hline $\begin{array}{l}\text { Hernan- } \\
\text { dez }\end{array}$ & 2003 & $\begin{array}{l}\text { Cimicifuga racemosa for the treatment of hot flushes in women } \\
\text { surviving breast cancer. }\end{array}$ & $\begin{array}{l}\text { Caracas, } \\
\text { Venezuela }\end{array}$ & $\begin{array}{l}\text { Cimicifuga vs. control group; significant improve- } \\
\text { ment }\end{array}$ \\
\hline Hervik & 2009 & $\begin{array}{l}\text { Acupuncture for the treatment of hot flashes in breast cancer } \\
\text { patients, a randomized, controlled trial. }\end{array}$ & $\begin{array}{l}\text { Tonsberg, } \\
\text { Norwegen }\end{array}$ & $\begin{array}{l}\text { Acupuncture vs. sham-acupuncture; acupuncture } \\
\text { led to larger effect than sham-acupuncture }\end{array}$ \\
\hline Jacobs & 2005 & $\begin{array}{l}\text { Homeopathy for menopausal symptoms in breast cancer } \\
\text { survivors: a preliminary randomized controlled trial. }\end{array}$ & Seattle & $\begin{array}{l}\text { Classical homeopathy vs. homeopathic complex } \\
\text { agent vs. placebo; marginally better effect of } \\
\text { classical, individual prescription }\end{array}$ \\
\hline Jacobson & 2001 & $\begin{array}{l}\text { Randomized trial of black cohosh for the treatment of hot flashes } \\
\text { among women with a history of breast cancer. }\end{array}$ & New York & Cimicifuga vs. placebo; no significant difference \\
\hline Joffe & 2010 & $\begin{array}{l}\text { Augmentation of venlafaxine and selective serotonin reuptake } \\
\text { inhibitors with zolpidem improves sleep and quality of life in } \\
\text { breast cancer patients with hot flashes: a randomized, double- } \\
\text { blind, placebo-controlled trial. }\end{array}$ & Boston & $\begin{array}{l}\text { Comparison of SSRI/SNRI } \pm \text { zolpidem; combina- } \\
\text { tion therapy superior with regard to sleeping }\end{array}$ \\
\hline $\begin{array}{l}\text { Kene- } \\
\text { mans }\end{array}$ & 2009 & $\begin{array}{l}\text { Safety and efficacy of tibolone in breast-cancer patients with } \\
\text { vasomotor symptoms: a double-blind, randomised, non- } \\
\text { inferiority trial. }\end{array}$ & $\begin{array}{l}\text { Amster- } \\
\text { dam }\end{array}$ & $\begin{array}{l}\text { Tibolone vs. placebo; tibolone improved the } \\
\text { menopausal complaints, but also increased risk } \\
\text { of recurrence }\end{array}$ \\
\hline Kimmick & 2006 & $\begin{array}{l}\text { Randomized, double-blind, placebo-controlled, crossover study } \\
\text { of sertraline (Zoloft) for the treatment of hot flashes in women } \\
\text { with early stage breast cancer taking tamoxifen. }\end{array}$ & $\begin{array}{l}\text { Winston- } \\
\text { Salem, } \\
\text { USA }\end{array}$ & $\begin{array}{l}\text { Sertraline vs. placebo; sertraline significantly } \\
\text { better }\end{array}$ \\
\hline Kroiss & 2005 & $\begin{array}{l}\text { The effect of tibolone in postmenopausal women receiving } \\
\text { tamoxifen after surgery for breast cancer: a randomised, double- } \\
\text { blind, placebo-controlled trial. }\end{array}$ & Vienna & $\begin{array}{l}\text { Tibolone vs. placebo; significant action, no effect } \\
\text { on the endometrium (no data on recurrence rate) }\end{array}$ \\
\hline Lipov & 2008 & $\begin{array}{l}\text { Effects of stellate-ganglion block on hot flushes and night } \\
\text { awakenings in survivors of breast cancer: a pilot study. }\end{array}$ & $\begin{array}{l}\text { Hoffman } \\
\text { Estates; } \\
\text { USA }\end{array}$ & $\begin{array}{l}\text { Stellate-ganglion blockade; blockade is an effec- } \\
\text { tive therapy }\end{array}$ \\
\hline Loibl & 2007 & $\begin{array}{l}\text { Venlafaxine is superior to clonidine as treatment of hot flashes } \\
\text { in breast cancer patients - a double-blind, randomized study. }\end{array}$ & $\begin{array}{l}\text { Frankfurt/ } \\
\text { Main }\end{array}$ & $\begin{array}{l}\text { Venlafaxine vs. clonidine; venlafaxine significantly } \\
\text { better }\end{array}$ \\
\hline
\end{tabular}


Table 1 Survey of studies on supportive therapy for menopausal complaints under endocrine therapy for patients with breast cancer. (continued)

\begin{tabular}{|c|c|c|c|c|}
\hline Author & $\begin{array}{l}\text { Publica- } \\
\text { tion year }\end{array}$ & Study name & Location & Summary of contents \\
\hline Loprinzi & 1994 & Megestrol acetate for the prevention of hot flashes. & Rochester & Megestrol acetate vs. placebo; significant effect \\
\hline Loprinzi & 1998 & $\begin{array}{l}\text { Pilot evaluation of venlafaxine hydrochloride for the therapy } \\
\text { of hot flashes in cancer survivors. }\end{array}$ & Rochester & Venlafaxine effective in pre-post comparison \\
\hline Loprinzi & 2000 & $\begin{array}{l}\text { Venlafaxine in management of hot flashes in survivors of breast } \\
\text { cancer: a randomised controlled trial. }\end{array}$ & Rochester & Venlafaxine vs. placebo; significant improvement \\
\hline Loprinzi & 2002 & Phase III evaluation of fluoxetine for treatment of hot flashes. & Rochester & $\begin{array}{l}\text { Fluoxetine vs. placebo; fluoxetine significantly } \\
\text { better }\end{array}$ \\
\hline $\begin{array}{l}\text { Mac } \\
\text { Gregor }\end{array}$ & 2005 & $\begin{array}{l}\text { A randomised double-blind controlled trial of oral soy supple- } \\
\text { ments versus placebo for treatment of menopausal symptoms } \\
\text { in patients with early breast cancer. }\end{array}$ & Glasgow & Soy supplement vs. placebo; no difference \\
\hline Mariani & 2005 & $\begin{array}{l}\text { Hot-flashes in breast cancer survivors: effectiveness of low- } \\
\text { dosage fluoxetine. A pilot study. }\end{array}$ & Rome & $\begin{array}{l}\text { Fluoxetine significantly effective in pre-post } \\
\text { comparison }\end{array}$ \\
\hline Nikander & 2004 & $\begin{array}{l}\text { Effects of phytoestrogens on bone turnover in postmenopausal } \\
\text { women with a history of breast cancer. }\end{array}$ & Helsinki & $\begin{array}{l}\text { Isoflavones vs. placebo; endpoint: laboratory val- } \\
\text { ues for bone metabolism; marginally less turnover } \\
\text { under isoflavones }\end{array}$ \\
\hline Pandya & 2000 & $\begin{array}{l}\text { Oral clonidine in postmenopausal patients with breast cancer } \\
\text { experiencing tamoxifen-induced hot flashes: a University } \\
\text { of Rochester Cancer Center Community. }\end{array}$ & New York & Clonidine vs. placebo; significant improvement \\
\hline Pandya & 2004 & $\begin{array}{l}\text { Pilot study using gabapentin for tamoxifen-induced hot flashes } \\
\text { in women with breast cancer. }\end{array}$ & Rochester & $\begin{array}{l}\text { Gabapentin significantly better in pre-post com- } \\
\text { parison }\end{array}$ \\
\hline Pandya & 2005 & $\begin{array}{l}\text { Gabapentin for hot flashes in } 420 \text { women with breast cancer: } \\
\text { a randomised double-blind placebo-controlled trial. }\end{array}$ & Rochester & $\begin{array}{l}\text { Gabapentin in } 2 \text { different doses vs. placebo; gaba- } \\
\text { pentin } 900 \mathrm{mg} / \mathrm{d} \text { significantly better }\end{array}$ \\
\hline Quella & 1998 & $\begin{array}{l}\text { Evaluation of soy phytoestrogens for the treatment of hot flashes } \\
\text { in breast cancer survivors: A North Central Cancer Treatment } \\
\text { Group Trial. }\end{array}$ & Rochester & Soy isoflavones vs. placebo; no differences \\
\hline Quella & 2000 & $\begin{array}{l}\text { Long term use of megestrol acetate by cancer survivors for } \\
\text { the treatment of hot flashes. }\end{array}$ & Rochester & $\begin{array}{l}\text { Follow-up questioning of the patients of the } 1998 \\
\text { study; some continued to use megestrol with suc- } \\
\text { cess, no indications of side effects in long-term use }\end{array}$ \\
\hline Stearns & 2000 & $\begin{array}{l}\text { A pilot trial assessing the efficacy of paroxetine hydrochloride } \\
\text { (Paxil) in controlling hot flashes in breast cancer survivors. }\end{array}$ & $\begin{array}{l}\text { Washing- } \\
\text { ton }\end{array}$ & Paroxetin vs. placebo; significant effect \\
\hline Stearns & 2005 & $\begin{array}{l}\text { Paroxetine is an effective treatment for hot flashes: results from } \\
\text { a prospective randomized clinical trial. }\end{array}$ & $\begin{array}{l}\text { Washing- } \\
\text { ton }\end{array}$ & $\begin{array}{l}\text { Paroxetin vs. placebo; paroxetin significantly } \\
\text { better }\end{array}$ \\
\hline $\begin{array}{l}\text { Thomp- } \\
\text { son }\end{array}$ & 2005 & $\begin{array}{l}\text { A pilot, randomized, double-blinded, placebo-controlled trial } \\
\text { of individualized homeopathy for symptoms of estrogen with- } \\
\text { drawal in breast-cancer survivors. }\end{array}$ & Bristol & $\begin{array}{l}\text { Homeopathic consultation + homeopathic drugs } \\
\text { or placebo; no difference }\end{array}$ \\
\hline $\begin{array}{l}\text { Thomp- } \\
\text { son }\end{array}$ & 2008 & Levetiracetam for the treatment of hot flashes: a phase II study. & Rochester & $\begin{array}{l}\text { Levetiracetam significantly reduced menopausal } \\
\text { symptoms }\end{array}$ \\
\hline $\begin{array}{l}\text { Van } \\
\text { Patten }\end{array}$ & 2002 & $\begin{array}{l}\text { Effect of soy phytoestrogens on hot flashes in postmenopausal } \\
\text { women with breast cancer: a randomized, controlled clinical trial. }\end{array}$ & Vancouver & $\begin{array}{l}\text { Isoflavone-rich soy drink vs. rice drink; marked } \\
\text { improvement in both groups, no difference }\end{array}$ \\
\hline Walker & 2010 & $\begin{array}{l}\text { Acupuncture versus venlafaxine for the management of vaso- } \\
\text { motor symptoms in patients with hormone receptor-positive } \\
\text { breast cancer: a randomized controlled trial. }\end{array}$ & Detroit & $\begin{array}{l}\text { Acupuncture vs. venlafaxine; both arms } \\
\text { comparable }\end{array}$ \\
\hline Weitzner & 2002 & $\begin{array}{l}\text { A pilot trial of paroxetine for the treatment of hot flashes and as- } \\
\text { sociated symptoms in women with breast cancer. }\end{array}$ & $\begin{array}{l}\text { Tampa, } \\
\text { USA }\end{array}$ & $\begin{array}{l}\text { Paroxetine significantly effective in pre-post } \\
\text { comparison }\end{array}$ \\
\hline Wu & 2010 & $\begin{array}{l}\text { The efficacy of sertraline for controlling hot flashes in women } \\
\text { with or at high risk of developing breast cancer. }\end{array}$ & Houston & Sertraline vs. placebo; sertraline not superior \\
\hline
\end{tabular}

and thus possess a potential for interactions were tested in the studies. One such example is the studies on paroxetine with initially positive evidence of efficacy in regard to the primary endpoint and formulation of corresponding therapy recommendations. The question of safety first arose later and the corresponding recommendations were revised $[57,58]$.

For all studies on supportive therapy, irrespective of whether they come from the field of complementary medicine or conventional therapy, a prior clarification of possible interactions should be undertaken. Neither for conventional nor for complementary medicine should a lack of side effects and interactions be proposed in the absence of an exact analysis.

For ethical reasons the performance of a study is only justifiable when
1. interactions can be excluded with certainty or, respectively

2. when this is not possible and/or also cannot be confirmed by further preclinical research, intensified precautionary measures should be undertaken for the participating patients.

In every case, suitable parameters such as survival and recurrence data should be required as secondary endpoints even for studies on purely supportive therapies, although this may need a longer follow-up period and thus longer time to achieve publishable results with higher study costs or, respectively, influence the approval of a new drug. For the case of highly unlikely interactions, a minimal requirement must be that a follow-up is undertaken and that as soon as data become available they are published and presented so that renewed scientific discussion 
and control of the approval may take place. Here, if necessary, innovative models such as cooperation with clinical cancer registers should be considered.

In studies on new drugs, increasingly comprehensive lists of drugs and natural substances that should not be consumed during the study period are being compiled - although this facilitates the performance of the study, the later implementation in healthcare reality becomes more difficult and, possibly, may even endanger the safety of the patient when these restrictions are not followed. Although the latter increases for the study participants in this process, the gaps in knowledge and the danger of later interactions outside of the study increase subsequently for patients treated in clinical routine outside of the studies. This restrictive procedure also strongly reduces the number of patients who may later be eligible for the therapy. The question is how can we avoid this dilemma? There is certainly doubt that confirmed interactions with clinical consequences must be excluded. On the other hand it is the clinical relevance that we must take into consideration - not every impact on an enzyme in the laboratory leads to clinical relevance. In these cases measurements of serum levels of the drug may provide useful hints. Unchanged levels, however, do not exclude other types of interaction (e.g., in the tumour cell). Thus, in cases of doubt only an analysis of survival parameters can lead to important deductions.

For the practicing physician it is important to have a good knowledge of the various therapeutic possibilities for hormone withdrawal symptoms in patients with breast cancer. It is also worthwhile to be aware of the good data concerning non-drug procedures such as physical activity, relaxation processes and cognitive movement exercises (Tai Chi, Qigong and Yoga).

\section{Facit for Practitioners}

$\nabla$

Hormone withdrawal symptoms are a frequent occurrence that leads to premature therapy termination by many breast cancer patients. Therapeutic substances of both conventional and complementary medicine are currently available. In both fields, drug interactions must be expected. This question is often not considered in clinical studies so that the prescribing physician must acquire additional information. A primary attempt with non-drug procedures such as physical activity, relaxation processes and cognitive movement exercises (Tai Chi, Qigong und Yoga) is a recommendable option for many patients.

\section{Conflict of Interest}

$\nabla$

None.

\section{References}

1 Hadji $P$ et al. Onkologie. Non-Compliance in der adjuvanten, endokrinen Therapie des Mammakarzinoms. Geburtsh Frauenheilk 2007; 67: 497

2 Brucker S. Onkologie. Postmenopause: adjuvante endokrine Therapie des frühen hormonrezeptorpositiven Mammakarzinoms. Geburtsh Frauenheilk 2008; 68: 847

3 Distler Wet al. Unerwünschte gynäkologische und operative Interventionen bei der Behandlung des postmenopausalen Mammakarzinoms mit Anastrozol und Tamoxifen. Geburtsh Frauenheilk 2010; 70: 57

4 Bossart $M$ et al. Frühes Mammakarzinom - Lebensqualität nach Switch von Tamoxifen auf Exemestan. Geburtsh Frauenheilk 2011; 71: 847
5 Sparreboom A et al. Herbal interactions in the United States: potential adverse interactions with anticancer agents. J Clin Oncol 2003; 22: 2489-2503

6 http://www.fda.gov/Drugs/DevelopmentApprovalProcess/ DevelopmentResources/DrugInteractionsLabeling/ ucm080499.htm\#background; Stand: 30.8.2012

7 Zhang $L$ et al. Drug interactions evaluation: an integrated part of risk assessment of therapeutics. Toxicol Appl Pharmacol 2010; 243: 134145

$8 \mathrm{Hu} \mathrm{Z}$ et al. St. John's wort modulates the toxicities and pharmacokinetics of CPT-11 (irinotecan) in rats. Pharm Res 2005; 22: 902-914

9 Barton $D$ et al. Depomedroxyprogesterone acetate for hot flashes. J Pain Symptom Manage 2002; 24: 603-607

10 Barton DL et al. Prospective evaluation of vitamin $\mathrm{E}$ for hot flashes in breast cancer survivors. J Clin Oncol 1998; 16: 495-500

11 Bertelli $G$ et al. Intramuscular depot medroxyprogesterone versus oral megestrol for the control of postmenopausal hot flashes in breast cancer patients: a randomized study. Ann Oncol 2002; 13: 883-888

12 Biglia $N$ et al. Non-hormonal treatment of hot flushes in breast cancer survivors: gabapentin vs. vitamin E. Climacteric 2009; 12: 310-318

13 Biglia $N$ et al. Evaluation of low-dose venlafaxine hydrochloride for the therapy of hot flushes in breast cancer survivors. Maturitas 2005; 52: $78-85$

14 Bordeleau L et al. Multicenter, randomized, cross-over clinical trial of venlafaxine versus gabapentin for the management of hot flashes in breast cancer survivors. J Clin Oncol 2010; 28: 5147-5152

15 Buijs $C$ et al. Venlafaxine versus clonidine for the treatment of hot flashes in breast cancer patients: a double-blind, randomized crossover study. Breast Cancer Res Treat 2009; 115: 573-580

16 Carpenter JS et al. Randomized, double-blind, placebo-controlled crossover trials of venlafaxine for hot flashes after breast cancer. Oncologist 2007; 12: 124-135

17 Carpenter JS et al. Evaluating the role of serotonin in hot flashes after breast cancer using acute tryptophan depletion. Menopause 2009; 16: 644-652

18 Clover A et al. Homeopathic treatment of hot flushes: a pilot study. Homeopathy 2002; 91: 75-79

19 Deng $G$ et al. Randomized, controlled trial of acupuncture for the treatment of hot flashes in breast cancer patients. J Clin Oncol 2007; 25: $5584-5590$

20 Dyer J et al. A study to look at the effects of a hydrolat spray on hot flushes in women being treated for breast cancer. Complement Ther Clin Pract 2008; 14: 273-279

21 Elkins $G$ et al. Randomized trial of a hypnosis intervention for treatment of hot flashes among breast cancer survivors. J Clin Oncol 2008; 26: 5022-5026

22 Frisk J et al. Long-term follow-up of acupuncture and hormone therapy on hot flushes in women with breast cancer: a prospective, randomized, controlled multicenter trial. Climacteric 2008; 11: 166-174

23 Goldberg RM et al. Transdermal clonidine for ameliorating tamoxifeninduced hot flashes. J Clin Oncol 1994; 12: 155-158

24 Goodwin JW et al. Phase III randomized placebo-controlled trial of two doses of megestrol acetate as treatment for menopausal symptoms in women with breast cancer: Southwest Oncology Group Study 9626. J Clin Oncol 2008; 26: 1650-1656

25 Hernandez MG et al. Cimicifuga racemosa for the treatment of hot flushes in women surviving breast cancer. Maturitas 2003; 44 (Suppl. 1): S59-S65

26 Hervik J et al. Acupuncture for the treatment of hot flashes in breast cancer patients, a randomized, controlled trial. Breast Cancer Res Treat 2009; 116: 311-316

27 Jacobs J et al. Homeopathy for menopausal symptoms in breast cancer survivors: a preliminary randomized controlled trial. J Altern Complement Med 2005; 11: 21-27

28 Jacobson JS et al. Randomized trial of black cohosh for the treatment of hot flashes among women with a history of breast cancer. J Clin Oncol 2001; 19: 2739-2745

$29 \mathrm{Joffe} \mathrm{H}$ et al. Augmentation of venlafaxine and selective serotonin reuptake inhibitors with zolpidem improves sleep and quality of life in breast cancer patients with hot flashes: a randomized, double-blind, placebo-controlled trial. Menopause 2010; 17: 908-916

30 Kenemans $P$ et al. Safety and efficacy of tibolone in breast-cancer patients with vasomotor symptoms: a double-blind, randomised, noninferiority trial. Lancet Oncol 2009; 10: 135-146 
31 Kimmick GG et al. Randomized, double-blind, placebo-controlled, crossover study of sertraline (Zoloft) for the treatment of hot flashes in women with early stage breast cancer taking tamoxifen. Breast J 2006; 12: 114-122

32 Kroiss $R$ et al. The effect of tibolone in postmenopausal women receiving tamoxifen after surgery for breast cancer: a randomised, doubleblind, placebo-controlled trial. BJOG 2005; 112: 228-233

33 Lipov EG et al. Effects of stellate-ganglion block on hot flushes and night awakenings in survivors of breast cancer: a pilot study. Lancet Oncol 2008; 9: 523-532

34 Loibl S et al. Venlafaxine is superior to clonidine as treatment of hot flashes in breast cancer patients - a double-blind, randomized study. Ann Oncol 2007; 18: 689-693

35 Loprinzi CL et al. Venlafaxine in management of hot flashes in survivors of breast cancer: a randomised controlled trial. Lancet 2000; 356: 2059-2063

36 Loprinzi CL et al. Megestrol acetate for the prevention of hot flashes. N Engl J Med 1994; 331: 347-352

37 Loprinzi CL et al. Pilot evaluation of venlafaxine hydrochloride for the therapy of hot flashes in cancer survivors. J Clin Oncol 1998; 16: 2377-2381

38 Loprinzi CL et al. Phase III evaluation of fluoxetine for treatment of hot flashes. J Clin Oncol 2002; 20: 1578-1583

39 MacGregor CA et al. A randomised double-blind controlled trial of oral soy supplements versus placebo for treatment of menopausal symptoms in patients with early breast cancer. Eur J Cancer 2005; 41: 708714

40 Mariani L et al. Hot-flashes in breast cancer survivors: effectiveness of low-dosage fluoxetine. A pilot study. J Exp Clin Cancer Res 2005; 24: 373-378

41 Nikander $E$ et al. Effects of phytoestrogens on bone turnover in postmenopausal women with a history of breast cancer. J Clin Endocrinol Metab 2004; 89: 1207-1212

42 Pandya KJ et al. Gabapentin for hot flashes in 420 women with breast cancer: a randomised double-blind placebo-controlled trial. Lancet 2005; 366: 818-824

43 Pandya KJ et al. Oral clonidine in postmenopausal patients with breast cancer experiencing tamoxifen-induced hot flashes: a University of Rochester Cancer Center Community Clinical Oncology Program study. Ann Intern Med 2000; 132: 788-793

44 Pandya $\mathrm{KJ}$ et al. Pilot study using gabapentin for tamoxifen-induced hot flashes in women with breast cancer. Breast Cancer Res Treat 2004; 83: 87-89
45 Quella SK et al. Evaluation of soy phytoestrogens for the treatment of hot flashes in breast cancer survivors: A North Central Cancer Treatment Group Trial. J Clin Oncol 2000; 18: 1068-1074

46 Quella SK et al. Long term use of megestrol acetate by cancer survivors for the treatment of hot flashes. Cancer 1998; 82: 1784-1788

47 Rada $G$ et al. Non-hormonal interventions for hot flushes in women with a history of breast cancer. Cochrane Database Syst Rev 2010; 9: CD004923

48 Stearns $V$ et al. A pilot trial assessing the efficacy of paroxetine hydrochloride (Paxil) in controlling hot flashes in breast cancer survivors. Ann Oncol 2000; 11: 17-22

49 Stearns $V$ et al. Paroxetine is an effective treatment for hot flashes: results from a prospective randomized clinical trial. J Clin Oncol 2005; 23: 6919-6930

50 Thompson EA et al. A pilot, randomized, double-blinded, placebo-controlled trial of individualized homeopathy for symptoms of estrogen withdrawal in breast-cancer survivors. J Altern Complement Med 2005; $11: 13-20$

51 Thompson $S$ et al. Levetiracetam for the treatment of hot flashes: a phase II study. Support Care Cancer 2008; 16: 75-82

52 Van Patten CL et al. Effect of soy phytoestrogens on hot flashes in postmenopausal women with breast cancer: a randomized, controlled clinical trial. J Clin Oncol 2002; 20: 1449-1455

53 Walker EM et al. Acupuncture versus venlafaxine for the management of vasomotor symptoms in patients with hormone receptor-positive breast cancer: a randomized controlled trial. J Clin Oncol 2010; 28: 634-640

54 Weitzner MA et al. A pilot trial of paroxetine for the treatment of hot flashes and associated symptoms in women with breast cancer. J Pain Symptom Manage 2002; 23: 337-345

$55 \mathrm{Wu}$ MF et al. The efficacy of sertraline for controlling hot flashes in women with or at high risk of developing breast cancer. Breast Cancer Res Treat 2009; 118: 369-375

56 Riechelmann RP et al. Drug interactions in oncology: how common are they? Ann Oncol 2009; 20: 1907-1912

57 Haddad $A$ et al. The pharmacological importance of cytochrome CYP3A4 in palliation of symptoms: review and recommendations for avoiding adverse drug interactions. Support Care Cancer 2007; 15: 251-257

58 Desmarais JE et al. Interactions between tamoxifen and antidepressants via cytochrome P450 2D6. J Clin Psychiatry 2009; 70: 1688-1697

Deutschsprachige Zusatzinformationen online abrufbar unter: www.thieme-connect.de/ejournals/toc/gebfra. 